x. Some place-names may have as many as two or three prefixes: e.g. Nya-mi-gudu, Ki-nya-ki-ti, Nya-lu-baha.

2. There are two suffixes: Ro and SI. The meaning of Ro is very uncertain: SENERo, TENGERO, CHOHERo. The meaning of SI (TSI) may be an abbreviation of MAZI-water, because we find it always in names of rivers.

3. It must be understood that there are many place-names without any prefix or suffix. Communicated by C. Vermunt

\title{
Spelling of African Place-names on Maps
}

The Linguistic Advisory Committee of the Institute, in consultation with the Place-names Committee of the Royal Geographical Society, has given much consideration to the difficult problem of the spelling of African place-names on maps. The matter was also discussed at the Deuxième Congrès de Toponymie et d'Anthroponymie in Paris last year, and a recommendation on the subject was recorded at the Conférence Internationale des Africanistes de l'Ouest at Bissau in December last. The complete lack of uniformity, or even of recognized principles of orthography, is a source of confusion and difficulty for students no less than for travellers. In a recent number of the Bulletin of the School of Oriental and African Siudies (vol. xii. 3 and 4, 1948), Dr. A. N. Tucker states the existing problem, reviews the various attempts which have been made periodically since 1745 to standardize the representation of geographical names, and describes the emergence of a new factor in the problem as it concerns Africa, in the wide adoption of a standardized orthography (the Institute's Africa orthography) for vernacular languages. Dr. Tucker considers that the attempt to introduce phonetic characters on maps would be premature, and recommends that where the standard alphabet of a language contains phonetic characters or letters with diacritics, a form of romanization should be worked out for use on maps; he suggests that, in general, the spelling recognized by local authorities should be followed for place-names on maps, and refers to a recommendation of the Congrès de Toponymie that the names adopted for places in West and Equatorial Africa should be those used by the natives of those places.

\section{Land Conservation and Utilization}

GovernMENTs in all parts of the world are becoming increasingly aware of the urgency of the problems connected with land conservation and use, particularly in tropical and subtropical areas. The numerous conferences of experts, the carrying out of soil surveys, and the establishment of research organizations and agricultural bureaux are indications that the fundamental importance of these problems is not ignored. In June of this year a conference on tropical and sub-tropical soils was held at the Rothamsted Experimental Station, England, when the Under-Secretary of State for the Colonies welcomed guests from the United States, France, Belgium, and Holland. The committee for Colonial Agricultural, Animal Health, and Forestry Research organized conferences at Nairobi in 1946 and 1947, at which improved arrangements for agricultural and veterinary research in East Africa were initiated and the need for a comprehensive soil survey was stressed. During 1947 a soils sub-committee was appointed to specialize in soil science research. In West Africa much attention has been paid in recent years to problems of agricultural production. Research into improved methods of rice production is being carried out in the Gambia, and the most extensive soil survey yet undertaken in the Colonies is shortly to be started in the Gold Coast. The survey will cover an area of $5 x, 000$ square miles, largely tropical forest and savannah. Six Europeans and 120 trained Africans, as well as African labourers, will be employed, since the intention is that the survey shall be carried out by the inhabitants of the Gold Coast, and the first year's work will consist largely of training African staff. 